\title{
24 \\ ETHNORELIGIOUS NATIONALISM AND AUTOCRATIZATION IN SRI LANKA
}

\author{
Neil DeVotta
}

Sri Lankans take pride in their island being Asia's oldest democracy-given that the country achieved universal suffrage in 1931, some seventeen years before independence and merely three years after Britain allowed the vote for all its citizens. Since independence in 1948, the island has evidenced competitive politicking, with parties/coalitions alternating in power at the national level multiple times and dozens of elections held at the local and provincial levels. Political participation has also been high, with turnout at the 2015 and 2019 presidential elections exceeding 80 percent. Yet this is also a country that has hardly gone a decade since independence without experiencing major violence in the form of ethnic riots and pogroms, left-wing insurgencies, and a grotesque civil war between majority Sinhalese and minority Tamils that lasted nearly thirty years (DeVotta 2019). In the past decade, since the ethnic conflict ended in 2009, Christian Evangelicals and especially Muslims have experienced episodic violence thanks to prominent politicians and Buddhist monks fanning communalism (DeVotta 2018).

Sri Lanka thus represents a democratic paradox: its citizens passionately value the franchise and the country holds relatively free and fair elections even while tolerating ethnoreligious violence. The added irony is that much of the ethnoreligious violence is promoted and justified in the name of Buddhism, given that the island is viewed as a sanctuary for Buddha's teachings and Sinhalese nationalists consequently insist on Buddhist superordination and minority subordination. Post-independence Sri Lanka initially looked like it was on the road to being a liberal democracy. However, the Sinhalese Buddhist majoritarianism that took root made the country into an ethnocracy, in that the Sinhalese Buddhist nationalist ideology undermines equal citizenship by dictating that minorities live in the island thanks to majority sufferance (Uyangoda 1994; DeVotta 2007).

The mainly state-sanctioned and -tolerated violence that continues to get perpetrated with impunity to promote majoritarianism disqualifies the island being branded a liberal democracy notwithstanding its competitive and inclusive politics. To rank as a liberal democracy, a country must go beyond merely holding competitive and inclusive elections; it must also uphold civil liberties for all citizens irrespective of ethnicity and religion, ensure an independent judiciary that fearlessly enforces the rule of law, tolerate civil society, minimize corruption, and balance against executive overreach (Diamond 2019a, 19). These are lofty criteria, and thus ensuring 
liberal democracy in even democratically consolidated societies is a work in progress. This is because opportunistic leaders and populist movements can quickly undermine even robust democratic institutions. The specific causes promoting such destabilization in a particular country may vary, but some overarching reasons attributed for the ongoing global democratic regression include demo-sclerosis in the United States, the Iraq War and the attendant delegitimation of democracy promotion, the proclivity among some Eastern European elites for soft-authoritarianism, illiberal populism in western democracies stemming from an aversion to globalization and immigration, and China's spectacular rise and support for authoritarian leaders (Diamond 2019b; The Economist 2014).

For much of the world's history people lived under authoritarian rule. Indeed, even today approximately 68 percent of the global population lives in autocratic states (Alizada et al. 2021, 7). The compromises and individual self-restraint required to ensure democracy, especially in ethnoreligious societies rife with crosscutting cleavages, are so daunting that it makes the quest for democracy appear foolhardy and arrogant. It is with good reason Rousseau noted that "If there were a people of Gods, it would govern itself democratically. Such a perfect government is not suited to men" (Quoted in Simon 2004, 433). Yet Rousseau himself and others urged societies to aspire towards democracy because it remains the political system most likely to promote peace and economic growth. If it is widely acknowledged that democracies tend not to wage war against fellow democracies (Russett 1993), it is also clear that people living in authoritarian states are more likely to suffer from famine, endure greater rates of poverty and mental illness, and also experience lower life expectancy (Kasparov and Halvorssen 2017).

If communism's demise as a dominant ideology seemed to suggest democracy was bound to be the only governance game in town, this was arguably because scholars and policymakers initially overlooked how elites in post-communist and post-authoritarian states with a proclivity to stay in power by hook or by crook were deft at manipulating societal cleavages to do so. Such elites and the hybrid regimes that consequently ensued have not only compromised these newly-democratized states (Carothers 2018), they have also goaded leaders in established democracies to embrace illiberal tactics to perpetuate power.

While the exact causes and extent of ongoing autocratization may be disputed (Levitsky and Ziblatt 2018; Mechkova, Luhrmann, and Lindberg 2017), we can agree that it "entails a deterioration of qualities associated with democratic governance" (Waldner and Lust 2018, 95). And while it is hard to pinpoint when precisely recent autocratization begins, the factors contributing to it are easily recognizable. These include corruption, executives seeking to operate extra-constitutionally and extra-judicially, and the state's inability to meet citizens' most basic needs (Diamond 2019a, 20). The manipulation of ethnoreligious cleavages and persecution of minorities for political gain and the absence of the rule of law, which prevents elites from being held to the same standards as everyone else, are other clear warning signs that the process of autocratization is in the works. As Larry Diamond notes, "No liberal democracy has ever just suddenly had a heart attack and died .... And it [does not] take the political scientist's version of a cholesterol test or an EKG to spot the emerging symptoms" (ibid). Consequently, while the world is yet to experience a full-blown third reverse wave leading to a large number of states ceasing to be democracies, there is no disputing that there has been a trend away from liberal democracy in the past fourteen years (Repucci 2020; Luhrmann and Lindberg 2019; Chu, Huang, Lagos, and Mattes 2020). Sri Lanka under especially the Rajapaksa family has contributed to this, although presidents who preceded the Rajapaksas laid the groundwork for autocratization.

Various exigencies can contribute to democratic backsliding. In Sri Lanka's case, ethnonationalism since the mid-1950s and the ensuing civil war that lasted nearly three decades 
led to security and sovereignty being privileged above individual rights and freedoms, and this cluster of factors especially compromised liberal aspects of democracy. Whatever the galvanizing reason at a given time, backsliding entails institutions that ensure transparency and horizontal accountability being weakened. It leads to checks on executive power being eroded, which typically gets done via new laws or referenda. The ensuing "executive aggrandizement" compromises good governance and promotes hybrid regimes (Bermeo 2016). In such instances, the pressure western democracies put on such regimes to counter their assault on civil society, civil liberties, and the rule of law could encourage opportunistic leaders to move closer to authoritarian states. Here too Sri Lanka stands out given how the Rajapaksas have gravitated towards China as part of a symbiotic relationship that has exacerbated corruption and autocratization.

That noted, democratic regression in Sri Lanka was baked at home and took shape in the 1950s, when Sinhalese Buddhist politicians eschewed consensus politics and instead pursued majoritarian politics that unleashed civil war. It is Sinhalese Buddhist majoritarianism combined with the civil war and authoritarian proclivities of certain leaders that compromised the island's democracy and pushed it in an autocratic direction (Tambiah 1986; Wilson 1988). In what follows, this essay briefly discusses how ethnonationalism contributed to democratic erosion in the island before critiquing the presidencies of Mahinda Rajapaksa (2005 to 2015) and Gotabaya Rajapaksa, brothers who together with their grasping family are most responsible for autocratization in Sri Lanka. The challenges stemming from the COVID-19 pandemic may have stymied Gotabaya Rajapaksa's majoritarian agenda, but the ensuing health and socioeconomic crises have allowed him to further militarize the island in ways that will make reversing autocratization extra difficult.

\section{Ethnonationalism and democratic regression}

As per Sri Lanka's most recent census, the Sinhalese comprise 74.9 percent of the population, while Sri Lankan Tamils, Indian Tamils, and Muslims are 11.2 percent, 4.1 percent, and 9.3 percent, respectively. In terms of religion, Buddhists are 70.1 percent, while Hindus, Christians, and Muslims are 12.6 percent, 7.6 percent, and 9.7 percent, respectively (Department of Census and Statistics Sri Lanka 2011). The island's demographics necessitated checks against majoritarianism. The absence of such structural constraints ensured it was only a matter of time before ambitious politicians played the Sinhalese Buddhist nationalist card to attain office. What ensued was a phenomenon of ethnic outbidding, which led to the main political partiesUnited National Party (UNP) and Sri Lanka Freedom Party (SLFP)—competing against each other on who could best provide for the majority community at the expense of especially the Tamil minority (DeVotta 2004).

Consequently, while Sri Lanka began its post-independence journey smacking of a liberal democracy, with one scholar noting that among the decolonized states the island had "the best chance of making a successful transition to modern statehood" (Wriggins 1961, 316), this promise was sundered within a decade. By the time the Sinhala language was instituted as the island's only official language in 1956, amidst riots against minority Tamils, the country was well on the way to becoming an ethnocracy, wherein belonging to the culturally dominant Sinhalese Buddhist nation trumps being a citizen of Sri Lanka (DeVotta 2018, 278; Smooha 2002). This is clear when one looks at the anti-minority and majoritarian policies that were instituted by the time the island celebrated a quarter century of independence in 1973: Tamil civil servants were forced to learn Sinhala to be promoted; Sinhalese civil servants were stationed in Tamil areas and Tamils forced to interact with them in Sinhala; Sinhala only was instituted 
into the courts system, including in the predominantly Tamil northeast region that Tamils consider part of their historic homeland; Tamil areas were provided little development assistance despite foreign aid earmarked for these regions; publications promoting Tamil culture from nearby Tamil Nadu state in India were banned; Tamil students were required to score higher than their Sinhalese peers to enter university; a quota system was developed to ensure that rural Sinhalese students got into the university more easily; and Sinhalese from the south were transplanted to the northeast to promote Sinhalese colonization and alter the region's demographics. Additionally, Buddhism was provided the foremost place within the 1972 constitution. Thus, illiberal populism rooted in ethnonationalism has long been a feature of Sri Lankan politics (DeVotta 2002).

Majoritarianism engenders sullen minorities, and it is hardly surprising that Tamil youth felt the urge to rebel. When a Lessons Learned and Reconciliation Commission was set up to analyze the civil war, its members baldly said that "The root cause of the ethnic conflict in Sri Lanka lies in the failure of successive Governments to address the genuine grievances of the Tamil people" (quoted in Minority Rights Group International 2014). As one author aptly noted when referring to the anti-Tamil policies that were instituted, "If the gods had wished to destroy, the madness of Sri Lanka's rulers gave them every opportunity” (Harris 1990, 222).

It is debatable if an ethnically tranquil Sri Lanka will have prevented certain leaders from acting in authoritarian vein, but it is indisputable that the ethnic conflict enabled authoritarianism. In this context, the semi-presidential constitution instituted in 1978 allowed President J. R. Jayewardene to act arrogantly, while the war and its triumphalist aftermath allowed Mahinda Rajapaksa to operate autocratically. Ultimately, while the actions of these two leaders especially nudged the country towards autocratization, the expanding militarization and majoritarianism under President Gotabaya Rajapaksa is ramping up autocratization in the island.

Constitutions designed for democratic societies ideally incorporate checks and balances as a way to institutionalize stability over the long term. Jayewardene's constitution, however, was partly designed to ensure the UNP stayed perpetually dominant (Oberst 1984). Jayewardene was wont to brag that the only thing he could not do under his constitution was change a man into a woman and vice versa. In this spirit, he amended the constitution 16 times between 1978 and 1988, often in partisan and whimsical fashion. In 1980 he vindictively stripped SLFP leader Mrs. Sirimavo Bandaranaike of her civic rights for seven years (in retaliation for her previous extension of SLFP rule by two years until 1977) and expelled her from parliament, thereby ensuring that his most effective opponent could not challenge him for reelection in 1982 . He then refused to hold scheduled parliamentary elections that would most certainly have led to a loss of seats for the UNP and instead held a severely compromised referendum that extended the party's five-sixths majority for another term. He even forced all UNP ministers to turn in signed but undated resignation letters, which ensured that they followed his dictates. His attitude toward the democratic process was best captured when he boasted:

We are contesting the election to win and at a time most favorable to us. We intend ... to demolish and completely destroy the opposition politically. After that I say to you, roll up the electoral map of Sri Lanka. You will not need it for another ten years.

(Samarakone 1984, 86)

Jayewardene used his power to dominate and assault those who crossed him. For instance, he used hoodlums belonging to the UNP's labor union to suppress strikes, beat protesters, harass journalists and Supreme Court justices, and attack political opponents. These forces were also used to foment anti-Tamil riots in 1977 and 1983, with dire consequences for the island. All 
this took place amidst the escalating ethnic conflict, which helped justify executive overreach. Ranasinghe Premadasa, Dingiri Banda Wijetunga, and Chandrika Bandaranaike Kumaratunga followed Jayewardene as executive presidents between 1989 and 2005, with Wijetunga serving just 18 months to wrap up Premadasa's term after the separatist Liberation Tigers of Tamil Eelam (LTTE) assassinated him in May 1993. While Premadasa and Kumaratunga engaged in petty politicking and also abused their authority as president, their regimes were more illiberal than autocratic. That changed when Mahinda Rajapaksa succeeded Kumaratunga.

\section{Autocratization under Mahinda Rajapaksa}

No president undermined democratic governance as effectively and ruthlessly as Mahinda Rajapaksa. Sinhalese Buddhists had long overlooked spreading illiberalism, because the ethnocracy that came with this benefitted them materially and those who faced the consequences of illiberalism were mainly Tamils (DeVotta 2021b). However, the post-war illiberalism President Rajapaksa and his family instituted sought to create a Rajapaksa dynasty by undermining the state. As one of President Rajapaksa's younger brothers bragged in reference to family rule, "an era of 'ruler kings' has begun" (The Economist 2010, 49).

Rajapaksa became president in November 2005 and soon thereafter nearly 140 members of his immediate and extended family took over various government positions. Three Rajapaksa brothers, by virtue of controlling nearly 80 government portfolios, arrogated to themselves between 60 and 70 percent of the country's budget. For instance, Mahinda Rajapaksa, besides being president, was also the minister for defense, finance, highways, planning, and ports and aviation. These combined portfolios placed 78 government institutions directly under his control. While charming and politically savvy, the president brooked little dissent. His older brother, Chamal, was Speaker of Parliament. His younger brother, Basil, was the Minister of Economic Development, which included the Board of Investment and the Tourist Promotion Bureau. Gotabaya, another brother who is now the island's president, was the country's Defense Secretary. In addition to superintending the armed forces, police, and coast guard, Gotabaya Rajapaksa also oversaw immigration and emigration, the Land Reclamation and Development Corporation, and the Urban Development Authority. Mahinda Rajapaksa's son, Namal, was a member of parliament and was being groomed to succeed him. Namal and Basil routinely overrode decisions by ministers; and those seeking a government job typically had to have their approval. This led to a supine cabinet of ministers who dared not cross Rajapaksa lest they lost their positions and perks.

During the Rajapaksa years opposition politicians were harried, civil society was neutered, and thugs associated with the regime operated with impunity. Self-censorship was routine and those who criticized the regime or military were murdered or disappeared (Helf et al. 2015, 3-4). White vans operated by rouge units within the military were used for such purposes. Businesses, ranging from insurance companies to banks, were infiltrated via board membership and their policies influenced in ways that benefitted ruling politicians and hurt the regime's competitors. Such autocratic capture allowed the government to starve independent media and the opposition of resources. Instead of accommodating the defeated and broken Tamils in some fashion, the regime further humiliated them especially in Northern Province by resorting to militarization and tolerating predatory behavior among soldiers and regime supporters (DeVotta 2016).

The extent of the government's arrogance was evidenced when Rajapaksa targeted retired army commander Sarath Fonseka, who was responsible for the military strategy to defeat the LTTE but thereafter challenged Rajapaksa in the 2010 presidential election: he was forcibly 
dragged away from his office, court martialed for improper military procurements, divested of his civil rights and military honors, and sentenced to jail for three years.

The judiciary too was controlled, with telephone justice-whereby someone in the president's or attorney general's office called justices to tell them how to rule in certain casesbecoming common. The judiciary's weakened position and the government's authoritarian nature were especially highlighted when the country's first ever female Chief Justice was impeached in January 2013. Her sin was to rule that a government program designed to transfer funds to the Rajapaksas for patronage purposes was unconstitutional. An irate president set up a Parliamentary Select Committee (PSC) comprised of politicians from the ruling coalition that found her guilty of financial and official misconduct, which formed the basis for impeachment. This was done despite the Supreme Court ruling that the PSC had no right to investigate a senior judge and the Appeals Court ordering parliament to abandon the impeachment process. Civil society organizations, clergy members, foreign governments, and various international bodies likewise objected strenuously. President Rajapaksa disregarded their entreaties and summarily signed the order removing the Chief Justice, even as pro-government goons brandishing poles gathered outside her official residence to make sure she relinquished her post.

Rajapaksa's authoritarian proclivities were especially evident when he forced through the 18th Amendment to the constitution, which was incorporated in September 2010. The amendment abolished the 17th Amendment, which Sri Lanka's parliament passed unanimously in 2001 when Chandrika Kumaratunga was president. While it failed to achieve full enforcement, the amendment mandated the creation of a Constitutional Council with sole powers to appoint and dismiss commissioners overseeing elections, public service, police, finance, human rights, and bribery and corruption. The Constitutional Council was further empowered to appoint the chief justice and other justices in the Supreme Court, president and judges of the Court of Appeal, members of the Judicial Services Commission (excepting its chairman), attorney general, inspector general of police, auditor general, parliamentary commissioner for administration (or ombudsman), and secretary general of parliament. This was a belated attempt to halt political interference and promote independent, impartial, and professional operations among and within these institutions that were consistent with horizontal accountability (ibid).

The 18th Amendment did away with the Constitutional Council and empowered the president to appoint personnel to lead the institutions under its purview. The 18th Amendment also permitted the president to contest more than two terms, which President Rajapaksa utilized to run for a third term in January 2015. The president engineered crossovers from the opposition to ensure he commanded the requisite two-thirds majority to pass the amendment, and by some accounts some of these politicians were paid over half a million dollars to abandon the parties under whose banner they got elected.

Chauvinistic nationalists and their antisocial behavior can also play a major role in undermining democracy (Howe 2017), and Sri Lanka clearly has a fair share of these constituencies. The ethnoreligious strife in the island has been a boon for such elements, and politicians, businessmen, and religious bigots have eagerly used them for opportunistic purposes. Foremost among these in recent times is a Sinhalese Buddhist nationalist group called the Bodu Bala Sena (Buddhist Power Force, or BBS) that gained prominence by resorting to Islamophobia. The attacks against the Muslim community, which led to businesses, houses, and mosques being destroyed, were possible because the Mahinda Rajapaksa government tolerated the BBS and its ilk. Politics and cultural considerations rooted in Sinhalese Buddhist nationalism and economics have combined to unleash this Islamophobia (Haniffa 2017). But the ability of forces close to the government to operate with impunity was a big reason for the periodic, well-orchestrated postwar anti-Muslim rioting. 
Under Mahinda Rajapaksa, the attempts to prevent institutions operating independently and fan anti-minority sentiment were deliberate. The civil war against the ruthless and terrorist LTTE made doing so easier. The literature on exceptionalism suggests that during "exceptional" periods of crisis or transformation institutionalized norms, rules, and laws can become irrelevant and countries can, consequently, veer toward authoritarianism. For crises provide opportunities to superimpose radical change that established social orders may otherwise oppose (Neal 2006). The exceptions can be instituted via extrajudicial and extraconstitutional means or by simply creating new laws that overturn extant laws (Ericson 2007). With the state mainly responsible for ensuring security and sovereignty, even new bad laws are easily legitimated and institutionalized. When this takes place in relatively democratized societies, the inevitable result is a move toward illiberalism and autocratization.

Exceptionalism is rooted in fear and insecurity and therefore predisposes people to violence (Huysmans 2006). During the ethnic conflict, ensuring security came at the expense of minorities' civil liberties and civil rights. A case in point is the draconian Prevention of Terrorism Act (PTA), which remains on the books. The Act allows the security forces to arrest, detain, and leave incommunicado for eighteen months anyone suspected of terrorist activities. Thousands of Tamils were dragooned using the PTA and recently dozens of Muslims have also been taken into custody using its statutes.

The illiberalism associated with exceptionalism enables untrammeled executive power in ways that undermine the rule of law (Huysmans 2008). In this regard, too, Sri Lanka stands out. Indeed, the exceptionalism that undergirded the island's ethnocentric and counter terror policies is part of the same narrative and logic that was used to legitimize autocratic politics since it easily justified extraconstitutional and extrajudicial practices to ensure security. Civil wars necessitate counter-terror practices, and the longer the conflict the more draconian these practices can become. The upshot is that ethnic conflicts end up compromising democracy and over the long term can lead to authoritarianism (Horowitz 1993).

Mahinda Rajapaksa's unexpected defeat in January 2015 was considered a win for democracy. Notwithstanding corruption scandals that tarnished the regime's reputation early on, the national unity government that succeeded Rajapaksa certainly enabled a freer society. And despite the serious anti-Muslim rioting that took place in a couple of instances, minorities felt more secure under this national unity government compared to the Rajapaksa years. This government also sought to institute ethnic reconciliation mechanisms in accordance with Sri Lanka's agreements with the United Nations Human Rights Council (UNHRC), although the progress made was halting and slow. It, however, bungled intelligence reports that might have averted the 2019 Easter Sunday suicide bombings by Islamist terrorists on Christian churches and hotels that killed nearly 270 people. This coupled with the inability of President Maithripala Sirisena and Prime Minister Ranil Wickremesinghe to get along allowed Gotabaya Rajapaksa, the former defense secretary and Mahinda Rajapaksa's brother, to win the presidential election in November 2019.

\section{Autocratization under Gotabaya Rajapaksa}

Gotabaya Rajapaksa capitalized on the Easter Sunday terrorist attacks and his leadership during the civil war and promised to institute effective government. Leading Buddhist monks and mainly Sinhalese Buddhist professionals fed up with the previous regime's directionless governance played a leading role in supporting his candidacy. Prominent serving and retired military personnel likewise supported him. Consequently, the vast majority of Sinhalese Buddhists voted for him while the vast majority of minorities voted against him. 
Sri Lanka under Gotabaya Rajapaksa represents a militarized ethnocracy. This is reflected in how post-election spoils have been doled out. For instance, only three of 35 secretaries to ministries are ethnic minorities, while nearly all major appointees to leading state agencies are Buddhists. A number of military personnel accused of having perpetrated war crimes during the civil war were rewarded with prominent positions immediately after Gotabaya became president. Indeed, one former soldier who was court-martialed and whose death sentence, for killing eight Tamil civilians (including four children), was upheld by the Supreme Court was summarily pardoned by the new president. Some among such so-called ranawiru (war heroes) are now being encouraged to run for parliament (The Island 2020a) through the Rajapaksas' Sri Lanka Podujana Peramuna (Sri Lanka People's Front, or SLPP) even as the president has threatened to yank the country from international bodies that level war crimes charges against Sri Lankan military personnel (The Island 2020b). This was done after the government withdrew co-sponsorship of the UNHRC resolution, which the previous regime had initiated to pursue ethnic reconciliation and accountability for alleged war crimes during the civil war.

All this fits a pattern of disregarding minorities' concerns. For instance, when Sri Lanka celebrated its Independence Day in February 2020 and 2021, the Gotabaya Rajapaksa government prevented the national anthem being sung in Tamil, which the previous regime had reintroduced. Additionally, checkpoints were erected in some parts of Northern Province and surveillance of Tamil areas especially increased. On the one hand, military personnel and Sinhalese Buddhist nationalists have genuinely feared a recrudescence of Tamil separatism and the surveillance regime that was put in place in Tamil areas-partly using rehabilitated exLTTE cadre-is understandable. On the other hand, it is also clear that the surveillance system was used to keep Tamils marginalized and insecure even as avenues were created for Sinhalese Buddhist forces to colonize hitherto traditional Tamil (and Muslim) lands.

The Presidential Task Force for Archeological Heritage Management in the Eastern Province that the president created in June 2020 appears geared for this task. The Secretary to the Ministry of Defense, another retired military personnel alleged to have perpetrated war crimes, heads the task force, which initially comprised eleven members including two Buddhist monks. President Gotabaya Rajapaksa, who has set up a Buddhist Advisory Council comprising leading monks and meets with the group every month, subsequently added four more Buddhist monks to the task force. Over 75 percent of the population in Eastern Province are Tamils and Muslims, yet not one member from either community was included in the task force. The group's sinister agenda was made amply clear when a gazette authorizing the expansion of the task force stated that the archeological heritage in Eastern Province is influenced by Buddhism and hence "the guidance and patronage of the Venerable Maha Sangha is ... needed" to identify and manage the relevant areas (The Gazette of the Democratic Socialist Republic of Sri Lanka 2020). Nationalists want all nine provinces to contain mainly Sinhalese Buddhists, and a policy of ethnic flooding à la that pursued in China's Tibet and Xinjiang regions could expeditiously achieve this result. In this regard, the expanding tentacles of China in the island not only stand to promote autocracy, they likely will also encourage ethnocracy.

The same day the task force pertaining to Eastern Province was created, Gotabaya Rajapaksa also created The Presidential Task Force to Build a Secure Country, Disciplined, Virtuous and Lawful Society. This body is comprised of military, intelligence, and police officials and its mandates appear designed to usurp the functions of civilian officials. Indeed, it is military personnel that President Gotabaya Rajapaksa has appointed to superintend the Sri Lanka Ports Authority, Telecommunication Regulatory Commission, Sri Lanka Customs, Consumer Affairs Authority, and Disaster Management Center. The president, who served in the military before emigrating to the United States seeking after greener pastures, has long held the police 
force in low esteem, and he has now placed the police and Criminal Investigation Division under the Defense Ministry.

The burgeoning autocratization amidst militarization does not bode well for civil society. For no sooner had Gotabaya Rajapaksa become president, NGOs began to be interrogated about personnel, funding sources, and individuals visiting them. And the defense ministry was also put in charge of registering NGOs. In the face of the COVID-19 crisis, numerous civil society groups have assisted the military to provide services, but this now leaves their personnel more exposed should the regime crack down on associational activities.

The task forces noted above were created amidst the COVID-19 pandemic, a clear indication that the economic crises stemming from the coronavirus hardly stopped the regime pursuing its autocratic and majoritarian trajectory. If anything, it has used the crisis to further militarize the country in ways that promote autocratization. Given that over 95 percent of the island's military forces are Sinhalese and Buddhist, this militarization conveniently combines an ethnonationalist agenda that threatens minorities and expands autocratization. For instance, the president picked the army commander (and not a public health official) to head the COVID-19 task force. The alleged war crimes committed by this officer were the basis for United States officials banning him and his family from visiting their country. And on January 1, 2021, the Gotabaya Rajapaksa government appointed a Major General in each of Sri Lanka's 25 districts to superintend coronavirus measures, thereby further expanding militarization.

In the early stages of the pandemic certain government personnel and pro-government media sought to blame Muslims for spreading COVID-19, and the government appeared to deliberately traumatize the community by insisting that Muslims who died of the coronavirus had to be cremated. The dictum was contrary to World Health Organization recommendations practiced throughout the world (Saroor 2020). The government, when seeking the support of predominantly Muslim countries like Pakistan and Bangladesh at the UNHRC, did change its policy in March 2021, which proved that the ban on COVID-19-related burials had less to do with science and more to do with humiliating and tormenting a Muslim community that voted overwhelmingly against both Mahinda Rajapaksa in 2015 and Gotabaya Rajapaksa in 2019.

Soon after Gotabaya Rajapaksa was elected, his brother and former president Mahinda was made prime minister. In March 2020, in accordance with the constitution, the president dissolved parliament six months before its term expired and called for elections the following month. The COVID-19 pandemic, however, forced the Elections Commission to postpone the polls twice. Article 70 of the country's constitution requires a new parliament to be in session within three months of the previous body being dissolved. Yet Gotabaya Rajapaksa refused to recall parliament, and during this period government expenditures and other business, including policies dealing with the coronavirus, were conducted without parliamentary oversight. Such autocratic governance could easily be repeated when the regime faces major crises and it may initially at least be tolerated among large portions of a public fed up with parliamentary anomie and malfeasance.

Notwithstanding the economic crises created by COVID-19 (Hewamanne 2021), Sri Lanka initially did well to curtail the spread of the virus. Sri Lankans across the ethnic divide appreciated the role the armed forces played in this regard. This, combined with the president's popularity among Sinhalese Buddhists and a weak opposition, allowed the SLPP to win 145 parliamentary seats and capture nearly 60 percent of the vote when elections were held in August 2020 (DeVotta 2021a).

Sri Lanka's parliament has 225 representatives and following the election the SLPP and its allies were easily able to form a supermajority. This allowed the Rajapaksas to pass the 20th Amendment to the constitution, which threw out the 19th Amendment or, otherwise 
put, reintroduced the 18th Amendment and most of its presidential prerogatives. If the 19th Amendment sought to limit presidential powers by empowering the prime minister, the 20th Amendment reverses this. Most Sinhalese Buddhists may associate a strong presidency and unitary state structure with sovereignty, but it is the executive presidential system that has enabled the tilt towards autocracy.

Amidst the ongoing COVID-19 crisis, the government set up a Presidential Commission of Inquiry into Political Victimization, which conveniently recommended the prosecution of lawyers associated with the Attorney General's Department, Bribery Commission, and Criminal Investigation Department who filed various charges against members of the Rajapaksa family, their cronies, and certain military personnel. President Gotabaya Rajapaksa and Prime Minister Mahinda Rajapaksa thereafter sought to use the commission's report to pass a resolution in parliament that summarily dismissed most charges, including cases undergoing trial. The charges in these cases range from murder and abduction, to money laundering and abusing state funds. This blatant attempt to promote impunity ensued even as the government flirted with stripping some opposition members of their civic rights, which would effectively marginalize them politically just as J. R. Jayewardene defanged Mrs. Bandaranaike by canceling her civic rights.

Today President Gotabaya Rajapaksa is also the Minister of Defense and Minister of Technology. Prime Minister Mahinda Rajapaksa is also the Minister of Finance; Economy and Policy Development; Buddhism and Cultural and Religious Affairs; and Urban Development, Water Supply and Housing Facilities. Chamal, another brother who was speaker of parliament during the previous Rajapaksa government, is Minister of Agriculture, Irrigation and Rural Development, Internal Trade, Food Security, and Consumer Welfare. A third brother, Basil, who is not a member of parliament, oversees two presidential task forces (Delivery of Essential Goods; and Economic Revival and Poverty Alleviation) and effectively uses the SLPP party network to channel COVID-19 aid. Mahinda Rajapaksa's son, Namal, is Minister of Youth and Sports. Altogether, the Rajapaksa clan controls around 140 of the 434 state institutions. Five years after being ousted from power, the family has recaptured the Sri Lankan state.

\section{Conclusion}

There can be no gainsaying that politicking rooted in ethnonationalism, the ensuing civil war, and the authoritarian predilections of leaders like Jayewardene and Mahinda Rajapaksa combined to undermine liberal democracy in Sri Lanka. None who worked closely with Gotabaya Rajapaksa associates him with pro-democracy either. Hitherto all Sri Lankan leaders matured politically within a parliamentary setting and the realization that parliament alone confers legitimacy forced them to seek the body's imprimatur even when enacting opportunistic legislation. Gotabaya Rajapaksa has little experience and regard for parliamentary procedures and niceties.

Prior to becoming president, Gotabaya Rajapaksa's service and career within government was military related; and while defense secretary he was known to disregard norms and rules associated with democratic governance. He promoted himself as a disciplinary nationalist technocrat while defense secretary, and it is that reputation that led Sinhalese Buddhists to vote for him. It is indeed instructive that a prominent Buddhist monk who pronounced blessings on Gotabaya Rajapaksa when he contemplated running for president said "Some people have described you as a Hitler. Be a Hitler. Go with the military and take the leadership of this country" (Sri Lanka Brief 2018). His decision-making since becoming president clearly indicates that he is likely to be more authoritarian than his predecessors. This will especially be the case once his brother Prime Minister Mahinda Rajapaksa leaves the political scene. 
And the long-term challenges stemming from COVID-19 will provide sufficient "exceptional" justifications for ruling autocratically.

Countries that have experienced democracy are more likely to want to change the regime than change the system. Even where autocracies have come to power amidst popular support (Pakistan is a case in point), people quickly sour on the autocrats. Consequently, the clamor to appear democratic is arguably stronger than ever. This normative power associated with democracy is a big reason illiberal leaders prefer hybrid regimes to full-fledged autocracy (Mechkova, Luhrmann, and Lindberg 2017, 168; Luhrmann and Lindberg 2019).

Hybrid regimes can endure for lengthy periods (Ottaway 2003; Levitsky and Way 2010), but elections can dethrone autocratic leaders and reverse autocratization (Lindberg 2006; Carothers 2018). This is partly because autocratic populists like Gotabaya Rajapaksa are good at selling quick solutions to extant crises yet fail to solve problems upon gaining power. Thus, even flawed elections are better than no elections, because they provide a disgusted populace the chance to change leaders causing democratic erosion. In short, elections can produce autocrats, but elections also oust autocratic regimes. Sri Lanka did prove this when it ousted a seemingly unconquerable Mahinda Rajapaksa from power in 2015.

Furthermore, the longer a country has enjoyed the franchise, the harder it may be for a despot to get rid of it. As noted earlier, Sri Lankans have had universal franchise since 1931. While this combined with ethnoreligious nationalism undermined the potential for liberal democracy, it nevertheless created a culture that values the right to vote. As per the 2018 Values and Attitudes Survey, 74 percent of Sri Lankans prefer democracy over other forms of governance (Center for Policy Alternative 2019, 36). This figure is high, and it is way above the 66 percent threshold used to determine democratic consolidation status (Diamond 1999, 68-9). Only time will tell whether this appreciation will remain or if heightened ethnonationalism and the allure of strongman rule will cement autocratization.

\section{Bibliography}

Alizada, N., R. Cole, L. Gastaldi, S. Grahn, S. Hellmeier, P. Kolvani, J. Lachapelle, A. Lührmann, S. F. Maerz, S. Pillai, and S. I. Lindberg. (2021) Autocratization turns viral. Democracy report 2021. University of Gothenburg: V-Dem Institute.

Bermeo, N. (2016) “On democratic backsliding," Journal of Democracy, 27(1), pp. 5-19

Carothers, T. (2018) “The surprising instability of competitive authoritarianism," Journal of Democracy, 29(4), pp. 129-35.

Center for Policy Alternatives. (2019) Values and attitudes survey on 70 years of independence in Sri Lanka. Colombo: Center for Policy Alternatives.

Chu, Y., K. Huang, M. Lagos, and R. Mattes. (2020) “A lost decade for third wave democracies," Journal of Democracy, 31(2), pp. 166-81.

Department of Census and Statistics Sri Lanka. (2011) "Sri Lanka census of population and housing 2011." Available at: www.statistics.gov.lk/PopHouSat/CPH2011/index.php?fileName=pop43\&gp= Activities\&tpl=3.

DeVotta, N. (2021a) "Sri Lanka: The return to ethnocracy," Journal of Democracy 32(1), pp. 96-110.

DeVotta, N. (2021b) "The genesis, consolidation, and consequences of Sinhalese Buddhist nationalism,". In Rouhana N. N., and N. Shalhoub-Kevorkian (eds.) When politics are sacralized: Comparative perspectives on religious claims and nationalism. Cambridge: Cambridge University Press, pp. 187-212.

DeVotta, N. (2019) "Island of violence: Sinhalese Buddhist majoritarianism and ethno-religious conflict in Sri Lanka,". In Riaz A., Z. Nasreen, and F. Zaman (eds.) Political violence in South Asia. London/ New York: Routledge, pp. 167-81.

DeVotta, N. (2018) "Religious intolerance in post-civil war Sri Lanka," Asian Affairs 49(2), pp. 278-300.

DeVotta, N. (2016) “A win for democracy in Sri Lanka," Journal of Democracy 27(1), pp. 152-66.

DeVotta, N. (2007) Sinhalese Buddhist nationalist ideology: Implications for politics and conflict resolution in Sri Lanka. Policy Studies 40. Washington D.C.: East-West Center. 
DeVotta, N. (2004) Blowback: linguistic nationalism, institutional decay, and ethnic conflict in Sri Lanka. Stanford: Stanford University Press.

DeVotta, N. (2002) "Illiberalism and ethnic conflict in Sri Lanka," Journal of Democracy 13(1), pp. 84-98.

Diamond, L. (2019a) Ill winds: Saving democracy from Russian rage, Chinese ambition, and American complacency. New York: Penguin Press.

Diamond, L. (2019b) "Democracy demotion: How the freedom agenda fell apart," Foreign Affairs 98(4), pp. $17-25$.

Diamond, L. (1999) Developing democracy: Toward consolidation. Baltimore: Johns Hopkins University Press.

Ericson, V. E. (2007) Crime in an insecure world. London: Polity Press.

Haniffa, F. (2017) "Merit economies in neoliberal times: Halal troubles in contemporary Sri Lanka,". In Rudnyckyj, D. and Osella, F. (eds.) Religion and the morality of the market. Cambridge: Cambridge University Press, pp. 116-37.

Harris, N. (1990) National liberation. London: I. B. Taurus.

Helf, G., J. Aplon, S. Ludeman, M. Silva, J. Schaller, L. Carter and N. DeVotta. (2015) Democracy, human rights and governance assessment of Sri Lanka-updated report. Washington: United States Agency for International Development.

Hewamanne, S. (2021) "Pandemic, lockdown and modern slavery among Sri Lanka's global assembly line workers," Journal of International Women's Studies 22(1), pp. 54-69.

Horowitz, D. (1993) "Democracy in divided societies," Journal of Democracy 4(4), pp. 18-38.

Howe, P. (2017) "Eroding norms and democratic consolidation," Journal of Democracy 28(4), pp. 15-29.

Huysmans, J. (2008) "The jargon of exception—on Schmitt, Agamben and the absence of political society," International Political Sociology 2(2), pp. 165-83.

Huysmans, J. (2006) The politics of insecurity: Fear, migration and asylum in the EU. London: Routledge.

Kasparov, G. and T. Halvorssen. (2017) "Why the rise of authoritarianism is a global catastrophe," The Washington Post (February 13). Available at: at www.washingtonpost.com/news/democracy-post/wp/ 2017/02/13/why-the-rise-of-authoritarianism-is-a-global-catastrophe/

Levitsky, S. and D. Ziblatt. (2018) How democracies die. London: Penguin Books.

Levitsky, S. and L. Way. (2010) Competitive authoritarianism: Hybrid regimes after the Cold War. New York: Cambridge University Press.

Lindberg, S. I. (2006) Democracy and elections in Africa. Baltimore: Johns Hopkins University Press.

Luhrmann, A. and S. I. Lindberg. (2019) "A third wave of autocratization is here: What is new about it?' Democratization 26(7), pp. 1095-113.

Mechkova, V., A. Lührmann, and S. I. Lindberg. (2017) “How much democratic backsliding?" Journal of Democracy 28(4), pp. 162-69.

Minority Rights Group International. (2014) "State of the world's minorities and indigenous peoples 2014 - Sri Lanka." (July 3). Available at: www.refworld.org/docid/53ba8dd310.html

Neal, A. W. (2006) "Foucault in Guantanamo: Towards the archeology of the exception," Security Dialogue 37(1), pp. 31-46.

Oberst, R. (1984) “Proportional representation and electoral system change in Sri Lanka,". In Manor, J. (ed.) Sri Lanka in change and crisis. London: Croom Helm, pp. 118-33.

Ottaway, M. (2003) Democracy challenged: The rise of semi-authoritarianism. Washington, D.C.: Carnegie Endowment for International Peace.

Repucci, S. (2020) “The leaderless struggle for democracy," Journal of Democracy 31(2), pp. 137-51.

Russett, B. (1993) Grasping the democratic peace: Principles for a post-Cold War world. Princeton: Princeton University Press.

Samarakone, P. (1984) “The conduct of the referendum,”. In Manor, J. (ed.) Sri Lanka in change and crisis. London: Croom Helm, pp. 84-117.

Saroor, S. (2020) "From Aluthgama and post-Easter Sunday to COVID-19: Muslims again at the margins," Common Views (April 27). Available at: www.commonviews.org/from-aluthgama-and-posteaster-sunday-to-covid-19-muslims-again-at-the-margins/

Smooha, S. (2002) “The model of ethnic democracy: Israel as a Jewish and democratic state," Nations and Nationalism 8(4), pp. 475-503.

Simon, J. (2004) "Singing democracy: Music and politics in Jean-Jacques Rousseau's thought," Journal of the History of Ideas 65(3), pp. 433-54.

Sri Lanka Brief. (2018) “Top monk asks Sri Lanka’s ex-defence chief to return as 'Hitler”' (June 21). Available at: https://srilankabrief.org/2018/06/top-monk-asks-sri-lankas-ex-defence-chief-to-return-as-hitler/ 


\section{Nationalism and autocracy in Sri Lanka}

Tambiah, S. J. (1986) Sri Lanka: Ethnic fratricide and the dismantling of democracy. Chicago: University of Chicago Press.

The Economist. (2014) "What's gone wrong with democracy.' (March 1), pp. 47-52.

The Economist. (2010) "Beating the drum.' (November 18), p. 49.

The Island. (2020a) "Members of armed forces, police will hold positions in SLPP govts. - PM." (May 19). Available at: www.island.lk/index.php?page_cat $=$ article-details\&page $=$ article-details\&code_ title $=222470$

The Island (2020b) 'President vows to quit international outfits attacking SL unfairly'. (May 20). Available at: www.island.lk/index.php?page_cat $=$ article-details\&page $=$ article-details\&code_title $=222512$

The Gazette of the Democratic Socialist Republic of Sri Lanka (2020). Available at: http://documents.gov.lk/ files/egz/2020/6/2178-17_E.pdf

Uyangoda, J. (1994) "Ethnicity, nation and state formation in Sri Lanka: Antinomies of nation-building," Pravada 3, pp. 11-17.

Waldner, D. and E. Lust. (2018) "Unwelcome change: Coming to terms with democratic backsliding," Annual Review of Political Science 21, pp. 93-113.

Wilson, A. J. (1988) The breakup of Sri Lanka: The Sinhalese-Tamil conflict. Honolulu: University of Hawaii Press.

Wriggins, H. W. (1961) "Impediments to unity in new nations: The case of Ceylon," American Political Science Review 55(2), pp. 313-20. 